\title{
FINANCING MANAGEMENT OF SCHOOL OPERATIONAL FUND (BOS) IN IMPROVING LEARNING AT BABAHROT STATE JUNIOR HIGH SCHOOLS (SMPN) OF SOUTHWEST ACEH REGENCY
}

\author{
Hasmawati' ${ }^{1}$, Murniati AR ${ }^{2}$, Nasir Usman ${ }^{3}$ \\ 1,2,3 Graduate Program, Universitas Syiah Kuala, Indonesia \\ 1,2,3Jalan Teuku Nyak Arief No. 441, Kec. Syiah Kuala, Aceh \\ Email: 78hasmawati@gmail.com¹, murniatiar@gmail.com² ${ }^{2}$ nasirusman@gmail.com³
}

\begin{abstract}
:
In achieving the management objectives used and the resources that run them, this research objectives are: knowing the planning, use, supervision, control, and obstacle of BOS fund management to improve the quality of learning. The data collection method used qualitative method and data collection techniques through: observation, interviews and documentation studies. The research subjects were the principal, vice principal, treasurer, school committee, vice curriculum, and teachers. The results showed that the planning was formulated through RAPBS or RKAS by involving the deputy head, treasurer and committee, the use of funds in accordance with technical guidelines, supervision carried out by schools and agencies, accountability in the form of reports reported by the treasurer, and the obstacles faced were the procurement of school necessities that are not as desired. This means that when procuring highquality school needs, it must adjust to standard quality, then there will be no BOS fund overrun.
\end{abstract}

\begin{abstract}
Abstrak:
Dalam mencapai tujuan organisasi dipengaruhi manajemen yang diterapkan dan sumber daya yang menjalankannya, sesuai dengan itu tujuan penelitian ini adalah: untuk mengetahui perencanaan, penggunaan, pengawasan, pertanggungjawaban serta kendala dalam pengelolaan dana BOS untuk meningkatkan kualitas pembelajaran. Metode pengumpulan data menggunakan metode kualitatif dan teknik pengumpulan data melalui: observasi, wawancara dan studi dokumentasi. Subjek penelitian adalah kepala sekolah, wakil kepala sekolah, bendahara, komite sekolah, wakilkurikulum, dan guru. Hasil penelitian menunjukan bahwa perencanaan dirumuskan melalui RAPBS atau RKAS dengan melibatkan Wakil Kepala, bendahara serta komite, penggunaan dana sesuai dengan juknis, pengawasan dilaksanakan oleh pihak sekolah dan dinas, pertanggungjawaban berupa laporan yang dilaporkan oleh bendahara, dan kendala yang dihadapi adalah pengadaan barang kebutuhan sekolah yang terkadang tidak sesuai dengan yang diinginkan. Artinya pada saat pengadaan kebutuhan sekolah dengan kualitas tinggi harus menyesuaikan kualitas yang standar tidak terjadi pembengkakan dana BOS.
\end{abstract}

\section{Keywords:}

Financing, BOS Fund, Improving Learning

How to Cite: Hasmawati, Murniati, \& Usman, N. (2021). Financing Management of School Operational Funds (BOS) in Improving Learning at Babahrot State Junior High Schools (SMPN) of Southwest Aceh Regency. Lentera Pendidikan : Jurnal Ilmu Tarbiyah dan Keguruan, 24(2), 206-214. https://doi.org/10.24252/lp.2021v24n2i4. 


\section{INTRODUCTION}

The 1945 Constitution of the Republic of Indonesia in Chapter II article 3 explains that national education functions to develop the ability to form civilization of a dignified nation in the context of the intellectual life of the nation, and aims to develop the potential of students to become human beings who believe and fear the Almighty God, have noble character, healthy, knowledgeable, capable, creative, independent and become a democratic and responsible citizen.

To realize the function of national education, in the Law Number 20 of 2003 concerning the National Education System, it is stated that every citizen aged 7-15 years is required to attend basic education without charging fees based on the Law Number 20 of 2003 concerning the National Education System in Article 49 paragraph (1) which stipulates that: "Education funds other than educator salaries and official education costs, are allocated a minimum of $20 \%$ of the State Revenue and Expenditure Budget (APBN) for the education sector and a minimum of $20 \%$ of the Regional Revenue and Expenditure Budget (APBD)".

The form of the Indonesian government's policy to provide the success of the 9-year compulsory education is to channel various aids for the sustainability of education in Indonesia, one of which is to provide education costs called School Operational Funds (BOS) (Budaya, 2016). The cost of education plays an important role in the survival of the world of education (Wijaya, 2019). The importance of costs in a budget program is that the costs have the influence on the level of efficiency and effectiveness of activities in order to achieve the goals.

The BOS Fund is a government assistance fund in the education sector that is intended for every elementary and junior high school in Indonesia, as determined by the Ministry of National Education, namely: in the education financing management system, conceptually the BOS program is given to reduce the community's burden on education financing in the context of 9-year quality compulsory education, freeing up fees for all poor students from all kinds of fees, both in public and private schools, and easing the burden of school operating costs for students in private schools (Chairinda, Harun, \& Usman, 2016). Thus, financing should be managed properly and used to support the achievement of the goals that have been set (Mulyasa, 2005), because financing is one of the important resources in education (Rahman, 2017). On the other hand, education financing programs can encourage behavior change (Osteen, Muske, \& Jones, 2007).

In the implementation and management of the School Operational Fund (BOS), based on the BOS technical manual (Juknis), the Bos Fund is used to fund non-personnel operational costs, such as costs for consumable educational equipment, and direct costs in the form of power, water, services, maintenance of facilities and infrastructure, transportation activities, consumption, and taxes. In the use of the School Operational Fund, it is prioritized for non-personnel operational needs, not for investment and not for the welfare of teachers. Furthermore, Fattah in Ferdi (2013) stated that "the cost of education includes direct costs and indirect costs. The direct costs consist of the costs incurred for the purpose of implementing teaching and student learning activities in the 
form of purchasing learning equipment, learning facilities, transportation costs, teacher salaries, both those incurred by the government, parents, and students themselves. Meanwhile, the indirect costs are in the form of lost profits (earnings forgone) in the form of lost opportunity costs (opportunity costs) that are spent by the students during learning.

Furthermore, the Ministry of Education and Culture uses a mechanism for distributing BOS funds by transferring them to the APBD cash then to the school accounts. The Ministry of Education and Culture argues that this mechanism aims to give local governments greater authority in the distribution of BOS funds. In this way, it is expected that the management will be more timely, in the right amount, and without fraud. It is expected that BOS funds will be not transferred slowly, be cut, or even lead to fraud with a new mode (Chairinda, Harun, \& Usman, 2016).

The main problem with BOS fund lies in the slow distribution and management at the school level which is not transparent. So far, transfer delays have occurred due to various factors, such as delays in transfers by the central government and the length of time a cover letter for disbursement of funds was issued by the regional BOS manager team. As a result, the principal had to look for various sources of loans to overcome the delay. Based on the BPK audit of the BOS fund management for the 2017 fiscal year and the first semester of 2018 at 3.237 sample schools in 33 provinces, it was found that the deviation value of BOS fund was approximately Rp. 28 billion. Deviations occurred in 2.054 or 63.5 percent of the total school sample. The average deviation for each school reaches Rp. 13.6 million. The discrepancies in BOS fund were revealed, among others, in the form of providing transportation assistance abroad, PGRI donation fees, and incentives for PNS (civil servant) teachers. During the 2014-2019 period, the prosecutor's office and the police throughout Indonesia also succeeded in taking action against 33 corruption cases related to the school operational funds, including BOS fund. The state loss from this case is approximately Rp. 12.8 billion. In addition, as many as 33 witnesses consisting of the principal, head of the education office, and education office employees have been named suspects.

One way that can be done in overcoming the problems above is to manage the financing of School Operational Fund (BOS) properly. Handoko (2009: 8) said that management is the process of planning, organizing, directing and supervising the efforts of members of the organization and the use of resources and other organizational resources in order to achieve the organizational goals that have been set. In relation to education management, Engkoswara \& Komariah (2011: 89) defined that education management is one's effort to mobilize and provide opportunities for others to carry out work effectively, and to accept personal responsibility for achieving the measurement results set. Thus, educational management is more emphasized on the efforts of a leader to mobilize resources to achieve educational goals. Education cost management is concerned with the issue of where to source funds and how to allocate them. Fattah \& Nanang (2006) stated that financing management is an act of managing costs which includes recording, planning, implementation, accountability, and reporting. 
In improving learning in schools, it can be carried out by implementing well-planned operational fund management (BOS) financing. Improving the quality of learning facilities and infrastructure so that the learning process can improve.

Based on the description above, the researchers are interested in conducting research on the financing management of School Operational Fund (BOS) in order to improve learning in the school.

\section{RESEARCH METHOD}

This research approach is a form of qualitative research. The informants in this study were taken using a porposive sampling technique, namely taking the subject by determining the criteria of the informant. The subjects in this study were the principal (1 person), vice principal (1 person), treasurer (1 person), school committee (1 person), curriculum representative ( 1 person) and teacher (1 person). The instruments used in this study are: the researchers themselves as the main instrument and as the supporting instruments, namely observation sheets and interview guidelines. The data collection techniques used in this study are: observation, interviews and documentation studies. The data analysis technique used in this study is data reduction, namely summarizing, selecting important things found in the field, presenting data, namely brief, concise and clear descriptions related to the data obtained in the field, and drawing conclusions, namely all the data that have been obtained through the research, and data reduction and data presentation is the result of the research.

\section{RESULTS AND DISCUSSION}

\section{School Operational Funds (BOS) Planning in improving learning at SMPN Babahrot}

Based on the initial observations, the researchers observed various observable aspects including school facilities, students' conditions and several other aspects. From the results of observations, the researchers were also more enthusiastic in digging up as much information as possible in order to achieve maximum results. The following is the result of the researchers' interview with several schools located in the legal area of Babahrot subdistrict, which consists of SMP Negeri 2 Babahrot, SMP Negeri 3 Babahrot and SMP Negeri 4 Babahrot. Based on the results of interviews with school principal at SMP Negeri 2 Babahrot regarding the planning of BOS fund, the distribution of BOS funds is carried out based on the results of routine meetings and carried out by compiling programs that are adapted from technical guidelines (juknis) from the center. This activity is important to coordinate to be more compact and solid in carrying out school programs (Rahmi, 2019). The programs that have been prepared have been planned in advance to support the teaching and learning process in the school. The previously prepared programs have been planned and realized using BOS funds in accordance with the urgent needs needed for the learning process to improve learning in the school.

In planning financing, the school stakeholders collect various human resources owned. This is in order to maximize the planning for financing school operational funds from the interviews obtained, namely the process of gathering human resources in 
financing BOS funds by making decisions in routine leadership meetings, namely between the principal, vice principal, the curriculum developer as well as the treasurer and school committee. The school plans the activities quantitatively or with numbers embodied in the number of currencies that will be carried out for one year, the budget discloses the numerical organizational goals and programs contained in the School Income and Expenditure Budget Plan (RAPBS or RKAS). The fund distribution programs at SMP Negeri 2 Babahrot include: interpreting the plan to be implemented; drawing up a plan based on priorities, its implementation; determining the work program and program details; determining the need for the implementation of program details; calculating the required funds; and determining the source of funds to finance the plan.

Likewise, the results of the researchers' interview with the deputy principal regarding the planning for the distribution of BOS funds which are expected to be maximized as well as possible in the implementation of the next period, it can be explained that the method of planning and distributing BOS funds in schools so far has been by referring to the technical guidelines that have been set from the center and they are fully utilized to support the learning process in the state junior high schools (SMPN) with related parties in the distribution of BOS funds in schools.

The researchers' analysis also reveals that planning for the use of BOS funds is still around the problem of school completeness that has not been completed, the planning for financing BOS funds should lead to improving the quality of learning. Widiastuti, Hidayat, \& Dwimawanti (2012: 4) stated, "School Operational Fund (BOS) in the form of money or books is an assistance so that the students can go to school or at least can get an education whose target is for a minimum education that must be followed by most or at least $95 \%$ of all students, school-age children". Therefore, careful management is needed, especially what is done by the managers. Classically, there are four core managements, namely planning, organizing, mobilizing, and controlling. Therefore, the supervision will be easier to be carried out by a good management.

\section{The Use of School Operational Fund (BOS) Assistance in Improving Learning at SMPN Babahrot, Southwest Aceh Regency}

The use and distribution of BOS funds are carried out as an effort to improve the efficient learning process in schools. So far, Planning and use of BOS funds in schools are conducted hand in hand; planning for BOS funds use have been used in schools for various things, such as the users to add facilities and infrastructure in the schools. The results of interviews with the principal at SMP Negeri 2 Babahrot stated that the use of BOS fund in the school was carried out as a whole as far as the need to support the teaching and learning process in schools and directed to urgent interests and needs, such as if there was a shortage of learning books, the procurement of textbooks for learning was carried out. The students, the need for assistance to underprivileged students even for honorary teachers is also dispensed with for the sake of and facilitate the learning process in the school. The distribution of BOS funds for the learning process is up to $80 \%$ for the improvement of supporting infrastructure completeness in achieving smooth learning. Utilization in the use of BOS funds is carried out thoroughly to those who are necessary 
and prioritized so that the learning implementation process goes well. This is in line with the results of the research conducted by Ismail \& Sumaila (2020) which stated that the use of BOS funds is intended to finance school activities to improve the learning process and teacher professionalism. The parties involved in the distribution of BOS fund are the school principal, vice principal, treasurer, and school committees.

Furthermore, the results of interviews with the vice principal related to the process of using BOS fund in the school are such as: the use of BOS fund for the smooth learning and teaching process is carried out as efficiently as possible so as not to be constrained in the learning process, before the distribution, the regular meetings are held with the parties, involving in managing BOS fund in the school. The distribution direction is carried out entirely for the procurement of learning books, honorary teacher fees, completeness of student learning facilities and infrastructures. From the school side, $100 \%$ of the BOS fund were used for the learning process and the procurement of facilities and infrastructures. Meanwhile, the parties involved in the distribution are the principal, vice principal, treasurer and school committees.

The results of the interview with the treasurer at the school related to the distribution of BOS funds stated that: the distribution of BOS fund that had been carried out so far by the school before being disbursed was carried out at regular meetings of the BOS fund and then proceeded with the distribution direction. The amount of BOS fund disbursed for the learning needs is $100 \%$ and it also includes the procurement of facilities and infrastructure in the school, so that the learning process is not hampered. Utilization taken for the learning process in schools through BOS fund can improve the quality of learning so that the teachers and the students in carrying out the learning process do not experience a shortage of student supporting facilities and infrastructure. The parties involved in the distribution of BOS fund are the principal, vice principal, school committees, curriculum representative including the treasurer.

\section{Financing Accountability for the School Operational Fund (BOS) Assistance in Improving Learning at SMPN Babahrot, Southwest Aceh Regency}

An activity, both small and large, in the process of its implementation, requires financing both in terms of material and non-material. Financing in BOS as one of the supporting learning processes so that the learning becomes effective and efficient. The results of interviews conducted with the principal of SMP Negeri 2 Babahrot on the financial accountability report at the school, stated that: the preparation of the accountability report in the distribution of BOS fund was carried out by the treasurer of the school's BOS fund in accordance with the RKas agreed upon before the distribution was carried out. The contents of the responsibility are in the form of data on the distribution of BOS fund for the process of implementing learning and adding school facilities and infrastructures. The parties who are responsible for the distribution of BOS fund are the school principal, treasurer, and deputy principal. Meanwhile, the recipient of responsibility for the distribution of BOS fund is the treasurer of the BOS fund. The process of delivering accountability in the distribution of BOS fund as an effort to improve the learning process is by conducting regular meetings on the use of the BOS fund budget, led by the principal. 
Furthermore, an interview with the deputy principal of SMP Negeri 2 Babahrot regarding the accountability for the financing of BOS fund stated that: the BOS fund reports so far have been carried out by the BOS fund treasurer and adjusted to the proposed budget and the budget spent. Meanwhile, the content of accountability in the distribution of BOS funds is in the form of financial reports on the use of BOS fund. The party who is responsible for the distribution of BOS fund, namely the treasurer and the team for implementing activities at the school, which is carried out as difficult as financial reporting and the completion of expenditures, who receives responsibility for the distribution of BOS fund is the principal by conducting regular meetings as a result of the procurement of the needs in the school.

The results of the interview with the treasurer of SMP Negeri 2 Babahrot regarding the accountability of BOS fund stated that: the process of preparing the accountability report for the distribution of BOS fund that has been carried out so far is by compiling the suitability of the budget for filing and spending on the school needs. The contents of the responsibility in the distribution are in the form of data on the expenditure of BOS fund in the procurement of learning support needs in the school. The party responsible for the distribution of BOS fund is the team appointed to procure school supplies supported by physical evidence. The party receiving the responsibility is the principal by conducting regular meetings on the use of BOS fund in the school. The delivery process is carried out openly with the team appointed to procure school needs and with parties involved in managing BOS fund, namely the school principal, treasurer, deputy principal, curriculum representative and school committee.

According to Habsyi (2016), the education financing also demands accountability for education financing. Supervision is a shared responsibility from internal, external and community parties.

\section{CONCLUSION}

Planning for school operational financing involves all the resources owned by the school by planning the distribution of BOS fund based on the results of regular meetings and carried out by compiling programs that are adapted from technical instructions (juknis) from the center. The programs that have been prepared have been planned in advance to support the teaching and learning process in schools.

The use of BOS fund in the schools is carried out comprehensively as far as the need to support the teaching and learning process in schools and it is directed to urgent interests and needs, such as if there is a shortage of learning books, then procurement of textbooks for student learning is carried out, the need for assistance to underprivileged students even for honorary teachers are also assigned for the sake of and facilitate the learning process in the schools. The distribution of BOS fund for the learning process is up to $80 \%$ for the improvement of the completeness of supporting infrastructure facilities in achieving smooth learning. Utilization in the use of BOS fund is carried out thoroughly to those who are necessary and prioritized so that the learning implementation process can 
be run well. The parties involved in the distribution of BOS fund are school principal, vice principal, treasurer, and school committees.

The BOS fund reports have been carried out by the BOS fund treasurer and adjusted to the proposed budget and the budget spent. Meanwhile, the content of accountability in the distribution of BOS fund is in the form of financial reports on the use of BOS fund. The party responsible for the distribution of BOS funds is the treasurer and the school's activity implementation team, which is carried out as difficult as financial reporting and completion of expenditures. The one who receives responsibility for the distribution of BOS funds is the school principal by conducting regular meetings as a result of the procurement of the needs at the school.

\section{REFERENCES}

Budaya, B. (2016). Manajemen Pembiayaan Pendidikan pada Sekolah Dasar yang Efektif. Likhitaprajna. Jurnal Ilmiah. Fakultas Keguruan dan Ilmu Pendidikan, 18(1). https://likhitapradnya.wisnuwardhana.ac.id/index.php/likhitapradnya/article/v iew/27.

Chairinda, Harun, C. Z., \& Usman, N. (2016). Manajemen Pembiayaan Bantuan Operasional Sekolah Pada SMP Negeri 4 Birem Bayeun Di Kabupaten Aceh Timur. Jurnal Administrasi Pendidikan, 4(2), 40-50. http://www.jurnal.unsyiah.ac.id/JAP /article/view/4788.

Engkoswara, \& Komariah, A. (2011). Administrasi Pendidikan. Bandung: Alfabeta.

Fattah, \& Nanang. (2006). Ekonomi dan Pembiayaan Pendidikan. Bandung: Remaja Rosdakarya.

Ferdi, W. . (2013). Pembiayaan Pendidikan: Suatu Kajian Teoritis. Jurnal Pendidikan Dan Kebudayaan, 19(4), 563-578. https://doi.org/10.24832/jpnk.v19i4.310.

Habsyi, I. (2016). Manajemen Pembiayaan Pendidikan pada SMP Negeri 13 Kota Ternate. EDUKASI, 14(2). https://doi.org/10.33387/j.edu.v14i2.199.

Handoko, H. T. (2009). Manajemen. Yogyakarta: BPFE.

Ismail, F., \& Sumaila, N. (2020). Implementasi Manajemen Pembiayaan dalam Pengelolaan Dana Bantuan Operasional Sekolah (BOS) di Madrasah Aliyah Negeri 1 Bitung, Sulawesi Utara. Manageria: Jurnal Manajemen Pendidikan Islam, 5(1), 1-18. https://doi.org/10.14421/manageria.2020.51-01.

Mulyasa, E. (2005). Manajemen Berbasis Sekolah. Bandung: Remaja Rosdakarya.

Osteen, S., Muske, G., \& Jones, J. (2007). Financial Management Education: Its Role in Changing Behavior. Journal of Extension, 45(3). https://archives.joe.org/joe/2007june/rb2.php.

Rahman, A. (2017). Efisien dalam Pembiayaan Pendidikan untuk Meningkatkan Kualitas Pendidikan. Jurnal Elektika, 5(2). https://ojs.unm.ac.id/Eklektika/article/view/6 552.

Rahmi, S. (2019). Kompetensi Manajerial Kepala Sekolah dalam Meningkatkan Etos Kerja Tenaga Kependidikan di SMA N 2 Lhoknga Aceh Besar. Manageria: Jurnal 
Manajemen Pendidikan Islam, 4(2). https://doi.org/10.14421/manageria.2019.42 $-01$.

Widiastuti, G., Hidayat, Z., \& Dwimawanti, I. H. (2012). Analisis Kualitas Pelayanan Penyaluran Dana BosTahun 2013 di Dinas Pendidikan Kota Semarang. Journal of Public Policy And Management Review, 1(2). https://doi.org/10.14710/jppmr.v1i2.1307.

Wijaya, D. (2019). Manajemen Pendidikan Inklusif Sekolah Dasar. Jakarta: Prenada Media Group. 